\title{
Evaluation of Bone Turnover and DXA Markers in Premature Ovarian Failure
}

\author{
SMARANDA ADELINA PREDA ${ }^{1}$, FLORINA NECHITA2*, MARIA CRISTINA COMANESCU³, DANA MARIA ALBULESCU4, \\ MIHAELA J ANA TUCULINA ${ }^{5}$, ANDREEA DENISA DOCEA ${ }^{6}$, EMILIA BURADA7 ${ }^{7}$ RAMONA CONSTANTINA VASILE ${ }^{8}$, \\ MIHAELA MITROI ${ }^{9}$ \\ University of Medicine and Pharmacy of Craiova, PhD Student, 2-4 Petru Rares Str., 200349, Craiova, Romania \\ 2University of Medicine and Pharmacy of Craiova, Department of Medical Psychology, 2-4 Petru Rares Str., 200349, Craiova, \\ Romania \\ ${ }^{3}$ County Hospital Segarcea, Department of Obstetrical-Gynecology, 50 Unirii Str., 205400, Segarcea, Romania \\ 4University of Medicine and Pharmacy of Craiova, Department of Anatomy, 2-4 Petru Rares Str., 200349, Craiova, Romania \\ 5 University of Medicine and Pharmacy of Craiova, Department of Odontology, 2-4 Petru Rares Str., 200349, Craiova, Romania \\ 6University of Medicine and Pharmacy of Craiova, Department of Obstetrical-Gynecology, 2-4 Petru Rares Str., 200349, Craiova, \\ Romania \\ ZUniversity of Medicine and Pharmacy of Craiova, Department of Physiology, 2-4 Petru Rares Str., 200349, Craiova, Romania \\ 8University of Medicine and Pharmacy of Craiova, Department of Epidemiology and Primary Health Care Department, 2-4 Petru \\ Rares Str., 200349, Craiova, Romania \\ थUniversity of Medicine and Pharmacy of Craiova, Department of Oto-Rhino-Laringology, 2-4 Petru Rares Str., 200349, Craiova, \\ Romania
}

\begin{abstract}
Premature ovarian failure (POF) is a pathological condition of women of controversial etiology, but with significant physical and psychological consequences due to the occurrence of menopause at the age of 3040 years. Osteoporosis is thus a major consequence of POF that should be diagnosed early and monitored over time, taking into account the risks of fracture in early menopause. Bone mass density assessment by DXA and bone turnover markers are the diagnostic and osteoporosis monitoring methods in premature ovarian failure.
\end{abstract}

Keywords: premature ovarian failure, osteoporosis, bone markers

Premature ovarian failure (POF) is a pathological condition of women of controversial etiology, but with significant physical and psychological consequences due to the occurrence of menopause at the age of 30-40 years. Long-term effects of POF include cardiovascular disease, osteoporosis, infertility, psychological changes. The basis for these complications is hypogonadotropic hypogonadism, that is the decrease in estrogen and progesterone levels and the increase in gonadotropic hormones (FSH, LH).

Osteoporosis is thus a major consequence of POF that should be diagnosed early and monitored over time, taking into account the risks of fracture in early menopause, risks that are comparable to those in physiological menopause [1-10].

Regarding the psychological effects in POF, it is known and accepted that psychosocial factors, including the individual's reactivity to stress, affect the entire functioning of the body. The disruption of systems that manage the body's response to stress is observed in a multitude of medical problems and illnesses as it affects the individual's ability to adapt to new threatening situations and to carry out daily activities that become a challenge [11-13]. Stress thus affects the ability of the body to function evenly, including the reproductive function, compromising the functioning of the ovaries and the uterus [13], whereas psychological adaptation to stress involves prioritizing essential psychological and bodily functions in survival, and function reproduction, under these conditions, is less important [14-15]. As part of the psychological adaptation to stress, the hypothalamic-pituitary-adrenal axis mediates the functions of the hypothalamic-pituitary-gonadal axis, which is responsible for the maturation of the reproductive organs and the reproductive capacity of the body [15], so we can say that stress mentally and chronically psychologically contributes significantly to the impairment of fertility, is not just a consequence. And improving coping capacity and changing perceived stress levels has been shown to be determining in fertility [16], and some aspects of the mental state, such as concerns and content of internal discourse, have been shown to play a role as predictor of fertility [17]. Furthermore, the stressful social aspects of human life, such as the parental model and the relationship of the individual with it, have been included among the causes of infertility [18]. There is also scientific evidence regarding the implication of depression and / or its treatment in impairing the body's ability to cause both premature and natural menopause premature ovarian depression and insufficiency with common pathophysiological characteristics [19].

In our study, we evaluated biochemically and DXA a group of women with premature ovarian failure in order to determine bone mass density (BMD), pre- and postestrogen hormone replacement therapy, administered over a 24-month period.

\section{Experimental part}

We included 31 cases aged 20 to 33 years with POF supported by clinical and paraclinical symptoms. Thus, in all cases of the anamnesis, we retain bradimenorea and oligomenorea for more than 3 months. All patients come from the Endocrinology Clinic and have signed informed consent.

Examination of the pelvis by echography did not reveal pelvic tumors or other organic causes responsible for POF.

*email: florina.nechita@yahoo.com, Phone +40351-443522 
The biochemical chartincludes assessments of glucose, lipid metabolism, hormonal dosages: estradiol and progesterone dosing, LH and FSH dosing.

The bone marrow markers were also dosed: osteocalcin and CrossLaps.

We performed the DXA examination in all patients.

From the obtained values we extracted the mean values and the standard deviation.

\section{Results and discussions}

POF has a $1 \%$ incidence for women up to 40 years of age and an incidence of $0.1 \%$ for women up to 30 years of age [20-21].

The POF etiology is diverse and not very well known. As major causes are discussed the anomalies of chromosome $X$ [22], POF isolated associated with autosomal genetic mutations [23-24] autoimmune causes [25-26] infectious causes [27] and iatrogenic causes. All these factors lead to POF or premature menopause or hypogonadotropic hypogonadism. These endpoints are used to define this pathological condition involving both physical and psychological consequences, therefore endocrinologists, gynecologists, fertility specialists, psychologists must be trained in POF management.

Taking into account the diagnostic criteria for POF (age under 40 years, oligoamenorea for more than 3 months, decrease of estradiol and increase of FSH [20] the lot we studied complies with these criteria. From the etiological point of view in our group we did notidentify chromosomal, infectious or iatrogenic causes and we considered this condition to be a spontaneous cause, as it is mentioned in other studies [28].

Regarding carbohydrate metabolism, we obtained normal values $(76-110 \mathrm{mg} / \mathrm{dL})$ in 24 cases and increased values $(115-122 \mathrm{mg} / \mathrm{dL})$ in 7 cases.

The evaluation of serum levels of total cholesterol, lipid, triglycerides and LDL-cholesterol revealed normal values in all cases.

Regarding the hormonal picture, we observed gonadotropic growth (LH, FSH) and estradiol and progesterone decrease in $61 \%$ of cases (fig. 1, 2).

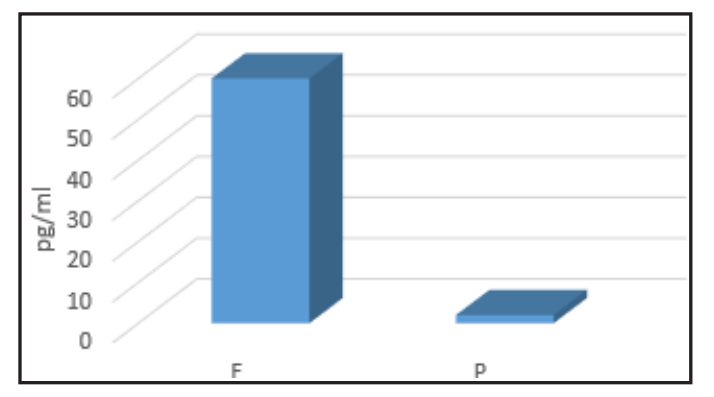

Fig. 1 Estrogen and progesterone values

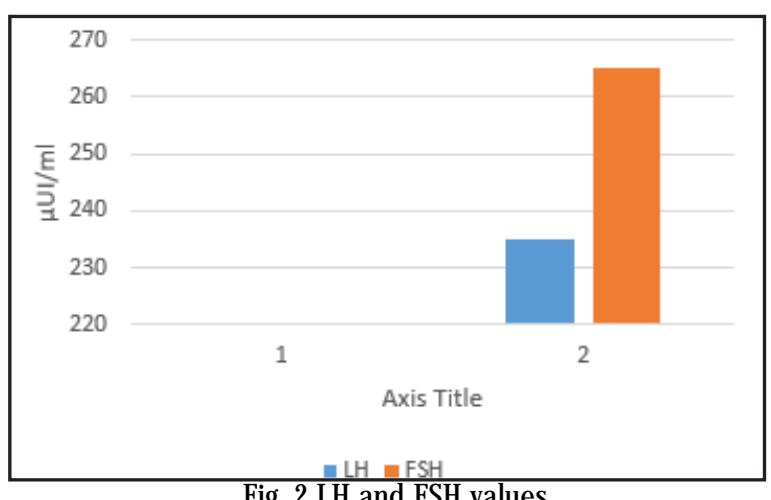

Fig. $2 \mathrm{LH}$ and FSH values
In 19 of the cases (61.2\%), hormonal dosages revealed low values for estradiol (Normal values $30-120 \mathrm{pg} / \mathrm{mL}$ ) and progesterone (normal values of $4.9-18.8 \mathrm{pg} / \mathrm{mL}$ ) and gonadotropics exceeded the upper limit of normal (Normal values LH 0.110-190 $\mu \mathrm{U} / \mathrm{mL}$, FSH normal values 0.110-190 $\mu \mathrm{U} / \mathrm{mL}$ ), as noted in figure 1 and 2 .

Considering the link between the role of estrogen in maintaining bone health, we find in our group that by lowering estrogen we have as a consequence the installation of osteoporosis in 10 patients, osteopenia in 12 patients and normal BMD in 9 patients, according to DXA results (table 1 ).

Table 1

BMD EVALUATION BY DEXA

\begin{tabular}{|l|c|c|}
\hline & $\begin{array}{c}\text { Number of } \\
\text { patience }\end{array}$ & Percent \\
\hline Osteoporosis & 10 & $32 \%$ \\
\hline Osteopenia & 12 & $39 \%$ \\
\hline $\begin{array}{l}\text { Normally } \\
\text { BMD }\end{array}$ & 9 & $29 \%$ \\
\hline
\end{tabular}

In addition to the biological picture defining the bone damage in POF, we also dosed bone markers showing a decrease in them comparable to women at menopause, a decrease that affected more than half of the study group.

Serum osteocalcin had values ranging from $22.9 \mathrm{ng} / \mathrm{mL}$ to $115 \mathrm{ng} / \mathrm{mL}$ in 12 cases (38\%), comparable to those of postmenopausal women.

In 7 cases (23\%) with secondary amenorrhoea for 4 years, osteocalcin limits were between $18.7 \pm 7.2 \mathrm{ng} / \mathrm{mL}$, comparable to premenopausal, while in other cases (39\%) were normal (less than $15 \mathrm{ng} / \mathrm{mL}$ )

Normal serum osteocalcin:

premenopausal women: $17.9 \pm 6.5 \mathrm{ng} / \mathrm{mL}$;

postmenopausal women: $18.4 \pm 9.5 \mathrm{ng} / \mathrm{mL}$;

The assessment of CrossLaps plasma levels revealed in cases with osteoporosis and osteopenia values ranging from $0.197 \mathrm{ng} / \mathrm{mL}$ to $1.768 \mathrm{ng} / \mathrm{mL}$, comparable to premenopausal and post-menopausal periods

Normal values for CrossLaps:

Premenopausal women: $0.166 \pm 0.476 \mathrm{ng} / \mathrm{mL}$;

- Postmenopausal women: $0.251 \pm 0.761 \mathrm{ng} / \mathrm{mL}$;

We mention that the patients included in the study did not associate chronic disease or medication that affects bone metabolism.

The administration of estrogen replacement therapy to our group over a 24-month period altered the values of bone markers in the sense of decreasing their values as follows:

Serum osteocalcin showed values ranging from 20.3 $\mathrm{ng} / \mathrm{mL}$ to $82.7 \mathrm{ng} / \mathrm{mL}$ in 19 patients, those with elevated or moderately elevated values compared to premenopausal or postmenopausal values of this bone turnover marker.

For the 11 cases that presented normal osteocalcin values from the beginning, these values remained within normal limits. We would like to point out that in the 19 patients with estrogen replacement therapy we also added bisphosphonate therapy.

For Cross Laps after 24 months of hormone replacement therapy, the values were between $0.672 \mathrm{ng} / \mathrm{mL}$ and 0.873 $\mathrm{ng} / \mathrm{mL}$.

DXA assessment of the patient population after 24 months shows a reduction in the number of patients with osteoporosis, a constant number of patients with osteopenia, and an increase in those with normal bone density (table 2). 
Table 2

BMD by DXA

\begin{tabular}{|l|c|c|}
\hline & $\begin{array}{c}\text { Number of } \\
\text { patience }\end{array}$ & Percent \\
\hline Osteoporosis & 6 & $19.35 \%$ \\
\hline Osteopenia & 12 & $38.7 \%$ \\
\hline $\begin{array}{l}\text { Normally } \\
\text { BMD }\end{array}$ & 13 & $41.9 \%$ \\
\hline
\end{tabular}

There is an improvement in bone health in 4 patients who initially had osteoporosis and in 4 patients who returned to normal bone density from osteopenia, demonstrating the positive effect of estrogen hormones on bone mass regulation and maintenance in order to reduce the risk of fracture of osteoporotic etiology.

Estrogen hormones have an important role in regulating bone growth, in regulating bone mass and maintaining it. Therefore, estrogen deficiency leads to osteoporosis, knowing that bone resorption increases up to $90 \%$ after menopause, and bone formation only increases to $45 \%$ [29-30]. These changes also occur in the case of POF by the significant decrease of estrogen hormones in this pathology, therefore osteoporosis is a consequence of the decrease in estrogen hormones. The degree of osteoporosis is demonstrated in our study by T-score values in relation to DXA, but we also evaluated the markers of bone turnover showing values comparable to premenopausal and postmenopausal. It is known that estrogen maintains the balance between bone formation and bone resorption through active mechanisms that suppress bone turnover [31]. Thus estrogens decrease the formation and activity of osteoclasts and increase their apoptosis [32-33]. However, there is still discussion of the action of estrogens in the differentiation, proliferation or suppression of osteoblasts [34-36]

All these considerations lead to the conclusion that bone can be considered an endocrine organ and the skeleton talks to the gonads [31].

The results of our study demonstrate the relationship between estrogen hormones and bone mass, thus the administration of estrogenic hormones has improved bone mass density.

Bone markers have values closer to normal values after hormone replacement therapy over a 24-month period, which shows the effect of estrogen hormones.

Observational studies in the field show the same positive effect of estrogens [37-39] on the bone, by the administration of estrogen hormones or contraceptive pills, the results being a reduction in the risk of fracture.

Of course, the administration of estrogen hormones in our group was initiated after the presentation of the risks (breast cancer, venous thromboembolism) to patients.

In the batch of treated patients and bisphosphonates, the results were similar in terms of bone turnover markers. We did not detect the occurrence of fractures or necrosis of the mandible, as side effects that may occur after bisphosphonate therapy [40-41].

If hormonal replacement and bisphosphonates are used for the treatment of osteoporosis, for psychological impairment a constant psychological support is indicated.

This diagnosis has short-term and long-term implications. Psychological and psychiatric symptoms accompanying the disturbance caused by the sudden appearance of the medical diagnosis of premature ovarian failure and its consequences have long been studied. They are not influenced by the patient's level of education or marital and ethnic status, age or working conditions, and are more intense, amplifying even distress, if the patient 2056 does not become a mother [42] and does not find or builds a sense of consistency, that is, a goal in her new life. The most important long-term effects are depression and anxiety, infertile patients being at greater risk than fertile healthy women [43] and being more stressed as the general population [44], and among the manifestations are irritability, distress, regret, malfunction of memory, insomnia, low concentration of attention, low self-esteem, shyness and social isolation [28,45-49].

For women who find this diagnosis closer to adolescence and before attempting to conceive a child, the news comes as a shock, it produces a lot of confusion, the experience has a higher traumatic potential, and their need for family support is more intense and the risk of depression is sustained throughout life. [43, 45, 48, 52]. Mother's role is often the essence of the female role and influences the other aspects of woman's life and identity, [42] the diagnosis signifying more than a sudden end to the fertile period and provoking a psychological process of premature aging [48]. As a result, the moment of transmission of the diagnosis is one of particular importance in the psychological evolution and recovery of the patient, most often perceived as a loss similar to the death of someone dear to the family with a moderate and severe level of suffering lived through helplessness, loss of control, helplessness, sadness, guilt, which will influence the way the patient will live with herself, that is, the body image, the aging process, the positive and the negative affections throughout life [43, 48, 50-52]. And because these symptoms are more intense in patients who feel more stigma and more uncertainty about their illness and their future, professionals need to train both in transmitting bad news as well as in the process of monitoring the evolution of the patient, who not only needs but also asks for help to learn to cope. The manner in which the bad news is transmitted and the way the patient is prepared for the moment deeply affects her short and long-term reaction from all points of view, and these patients will pose a risk of disturbing psychic functioning all their lives. The good news is that it can be diminished by a process of correct and patient-based news transmission and because social isolation and low perception of social support is a major problem in this case by offering a care system made up of health professionals with different approaches and available techniques, including annual assessments and specific interventions depending on the perceived and reported manifestations of the patient. [12, 16, 19, 42-43, 47-49, 52-55].

\section{Conclusions}

Bone mass density assessment by DXA and bone turnover markers are the diagnostic and osteoporosis monitoring methods in premature ovarian failure, and hormone replacement is the best treatment for preventing osteoporosis. Completing bisphosphonate therapy shows an improvement in bone health in this pathology.

Psychological impairment is one of the important consequences of premature ovarian failure on quality of life, so psychological support should playan importantrole in the complex treatment of this condition, taking into account the young age of patients with this pathological condition. Therefore, besides drug therapy for osteoporosis or prevention of osteoporosis, psychological therapy is also needed to improve the quality of life.

\section{References}

1. FAUBION, S. S., KUHLE, C. L., SHUSTER, L. T. AND ROCCA W. A., Climacteric 2015;18:1-9 
2. YOSHIDA, T., TAKAHASHI, K., YAMATANI, H., TAKATA, K., KURACHI H., Climacteric 2011;14:445-52

3. HADJIDAKIS, D. ., KOKKINAKIS, E.P., SFAKIANAKIS, M.E., RAPTIS,

S.A., Maturitas 2003; $44: 279-86$

4. FRANCUCCI, C.M., ROMAGNI, P., CAMILLETTI, A., et al, Maturitas 2008:59:323-8

5 VEGA, E.M., EGEA, M.A., MAUTALEN, C.A., Maturitas 1994;19:117-24 6. van DER KLIFT, M., DE LAET, C.E., MCCLOSKEY, E.V. et al., J Bone Miner Res 2004;19:1172-80

7. van DER VOORT, D.J., Van DER WEIJER, P.H., BARENTSEN, R., Osteoporos Int 2003;14:525-30

8. GARDSELL, P., JOHNELL, O., NILSSON, B.E., Calcif Tissue Int 1991:49:90-4

9. MELTON, L.J ., CROWSON, C.S., MALKASIAN, G.D., O'FALLON, W.M., J Clin Epidemiol 1996;49:1111-15

10. VESCO, K.K., MARSHALL, L.M., NELSON, H.D., et al., Menopause 2012;19:510-16

11. SONINO, N., GUIDI, J., FAVA, G.A., J R Coll Physicians Edinb 2015; 45: $55-9$

12. DANIELS, J., TURNER COBB, J.M., Clin Endocrinol 2017; 86: 772777.

13. WHIRLEDGE, S., CIDLOWSKI, J.A., Minerva Endocrinol. 2010;35(2):109-25.

14. SMITH, S.M., VALE, W.W., Dialogues Clin Neurosci. 2006;8(4):38395.

15. JOSEPH, D.N., WHIRLEDGE, S., Int. J. Mol. Sci. 2017, 18, p2224

16. DOMAR, A. D., ZUTTERMEISTER, P. C., SEIBEL, M., BENSON, H., Fertility and Sterility, 1992, 58(1), 144-147

17. STOLERU, S., TEGLAS, J. P., FERMANIAN, J.,SPIRA, A., Human Reproduction, 1993 8(7), 1039-1046

18. WASSER, S.K., SEWALL, G., SOULES, M.R., Fertility and Sterility, $1993,59,685-689$

19. HARLOW, B.L., CRAMER, D.W., ANNIS, K.M., American J ournal of Epidemiology, 141(12), 1995, 1170-1176

20. MACLARAN, K., PANAY, N., Womens Health (2015) 11(2), 169-182 21. COULAM, C.B., ADAMSON, S.C., ANNEGERS, J.F., Obstet Gynecol, $1986,67,604-606$

22. ALBULESCU, D.M., PREDA, A.S., CAMEN, A., IONOVICI, N., Rev Chim (Bucharest), 69, no. 7, 2018, 1692-1694

23. ZHAO, H., CHEN, Z.J., Mol Hum Reprod, 2013, 19, 644-654

24 PERSANI, L., ROSSETTI, R., CACCIATORE, C., J Mol Endocrinol, $2010,45,257-279$

25.SILVA, C.A., YAMAKAMI, L.Y., AIKAWA, N.E., ARAUJ O, D.B., CARVALHO, J.F., BONFA, E., Autoimmun Rev, 2014, 13, 427-430

26. NOVOSAD, J.A., KALANTARIDOU, S.N., TONG, Z.B. et al., BMC Womens, 2003, 3: 2

27. DE POMMEROL, M., HESSAMFAR, M., LAWSON-AYAYI, S. et al., Int J STD AIDS, 2011, 22, 67-72

28.NELSON, L.M., N Engl J Med, 2009, 360, 606-614

29. CLARKE, B.L., KHOSLA, S., Clin North Am 2010;48:483e95.

30. GARNERO, P., SORNAY-RENDU, E., CHAPUY, M.C., DELMAS, P.D., J Bone Miner Res 1996;11:337e49

31. OURY, F., Translational Endocrinology of Bone, 2013, pp.123-135 32. HUGHES, D.E., DAI, A., TIFFEE, J.C., LI, H.H., MUNDY, G.R., BOYCE, B.F., Nat Med, 1996; 2:1132e6.
33. IMAI, Y., YOUN, M.Y., KONDOH, S., NAKAMURA, T., KOUZMENKO. A., MATSUMOTO, T., et al., Ann N Y Acad Sci 2009;1173(Suppl1): E31e9 34.VANDERSCHUEREN, D., VANDENPUT, L., BOONEN, S., LINDBERG, M.K., BOUILLON, R., OHLSSON, C., Endocr Rev 2004;25:389e425 35. MAJESKA, R.J., RYABY, J.T., EINHORN, T.A., J Bone J oint Surg Am 1994;76:713e21.

36. QU, Q., PERALA-HEAPE, M., KAPANEN, A., DAHLLUND, J., SALO, J., VAANANEN, H.K., et al., Bone 1998;22:201e9

37. HAMODA, H., Post Reproductive Health 2017, Vol. 23(1) 22-351

38.CROFTON, P.M., EVANS, N., BATH, L.E., et al., Clin Endocrinol (Oxf) 2010; 73: 707-714.

39. CARTWRIGHT, B., ROBINSON, J ., SEED, P.T., et al., J ClinEndocrinol Metab 2016; 101: 3497-3505

40. KHOSLA, S., BURR, D., CAULLEY, J., et al., J Bone Miner Res 2007; 22: 1479-1491

41. SHANE, E., BURR, D., ABRAHAMSEN, B., et al., J Bone Miner Res 2014; 29: 1-23

42 MCQUILLAN, J., GREIL, A.L., WHITE, L., JACOB, M.C., Journal of Marriage and Family, 2003, 65(4), pp.1007-1018

43 DAVIS, M., VENTURA, J.L., WIENERS, M., COVINGTON, S.N., VANDERHOOF, V.H., RYAN, M.E., KOZIOL, D.E., POPAT, V.B., NELSON, L.M., Fertility and sterility, 2010, 93(7):2321-9

44. WRIGHT, J , ALLARD, M., LECOURS, A., SABOURIN, S., International Journal of Fertility, 1989, 34(2):126-42

45. PODFIGURNA-STOPA, A., CZYZYK, A., GRYMOWICZ, M., SMOLARCZYK, R., KATULSKI, K., CZAJ KOWSKI, K., MECZEKALSKI, B., Journal of endocrinological investigation, 2016, 39(9):983-90 46 SCHMIDT, P.J ., CARDOSO, G.M., ROSS, J.L., HAQ, N., RUBINOW, D.R., BONDY, C.A., SHYNESS, Jama, 2006, 295(12), 1373-8

47. SCHMIDT, P.) ., LUFF, J.A., HAQ, N.A., VANDERHOOF, V.H., KOZIOL, D.E., CALIS, K.A., RUBINOW, D.R., NELSON, L.M., The J ournal of Clinical Endocrinology \& Metabolism, 2011, 96(2), 278-87

48. NELSON, L.M., COVINGTON, S.N., REBAR, R.W., Fertility and sterility, 2005, 83(5), 1327-1332

49. SUTTON, E.J., MCINERNEY LEO, A., BONDY, C.A., GOLLUST, S.E., KING, D., BIESECKER, B., American J ournal of Medical Genetics Part A, 2005, 139(2), 57-66

50. RAFIQUE, S., STERLING, E.W., NELSON, L.M., Obstetrics and Gynecology Clinics, 2012, 39(4), 567-586

51. ORSHAN, S.A., FURNISS, K.K., FORST, C., SANTORO, N., J ournal of Obstetric, Gynecologic, \& Neonatal Nursing, 2001, 30(2):202-208

52. NIPPITA, T.A., BABER, R.J ., Climacteric, 2007, 10(1), 11-22

53. GROFF, A.A., COVINGTON, S.N., HALVERSON, L.R., FITZGERALD, O.R., VANDERHOOF, V., CALIS, K., NELSON, L.M., Fertility and sterility, 2005, 83(6), 1734-1741

54. CALBOREAN, V., CIOBANU, D., MIREA, S.C., GALCEAVA, O.,GHEORMAN,V.,PADUREANU, V.,FORTOFOIU, C.M., FORTOFOIU,M., MITA, A., DINESCU, S.N., MISCOCI, S.A., DINESCU, V.C. Benefit of Cardiac Resynchronization Therapy in Patients with Heart Failure. Rev. Chim. (Bucharest), 69, no. 9, 2018, p.2461-2464.

55. CALBOREAN, V., GHEORMAN,V., DINESCU, S.N., STANCA, D., GALCEAVA, O., FORTOFOIU, M., MITA, A., MIHAILOVICI, A.R., MISCOCl, S.A., DUMITRU BALEANU,V.,DINESCU, V.C., Arrhythmia Risk in Patients with Chronic Hepatic Disease. Rev. Chim (Bucharest) 69, no. 11, 2018, p. 4237-4240.

Manuscript received 11.01.2019 